\title{
Higher education in
}

a globalising world

Community engagement and lifelong learning

\section{Peter Mayo}

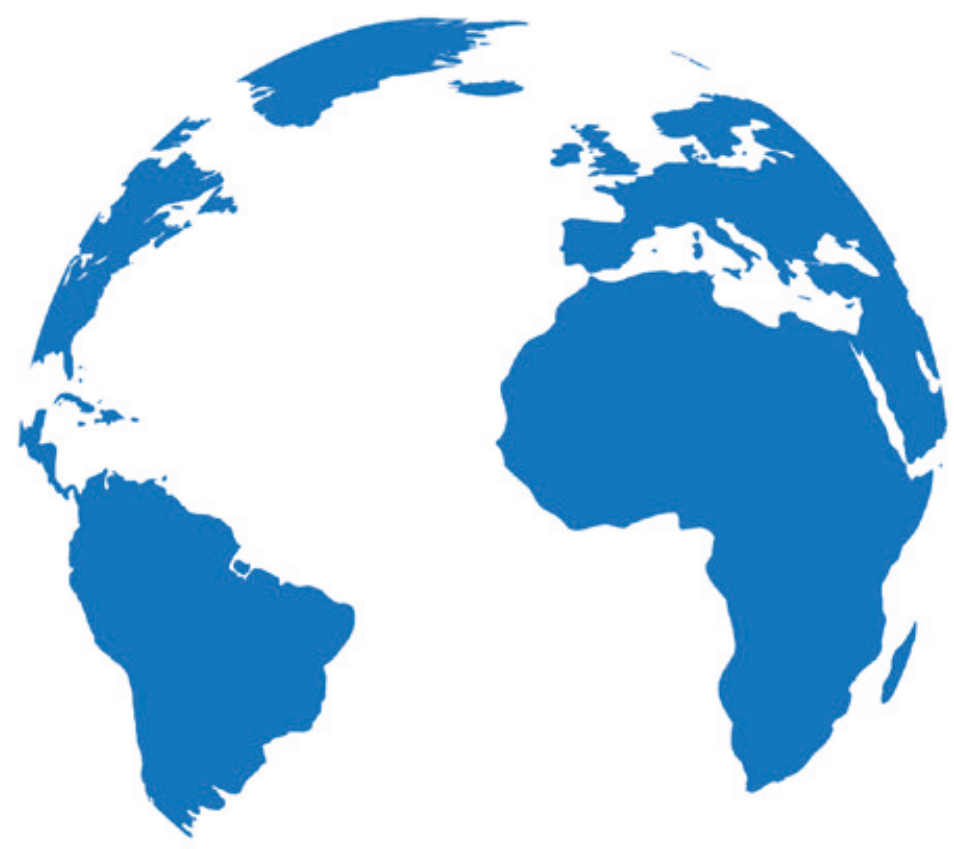

'A powerful appeal for the university to offer resistance to Neoliberalism'

Boaventura de Sousa Santos,University of Coimbra 


\section{UNIVERSITIES AND LIFELONG LEARNING}

Higher education in a globalising world

\section{MANCHESTER

Manchester University Press 


\section{UNIVERSITIES AND LIFELONG LEARNING}

Series editor:

Professor Michael Osborne (University of Glasgow)

Universities and lifelong learning analyses the external engagement activities of universities and third-level institutions and is concerned with the range of activity that lies beyond the traditional mission of teaching and research. This is an area that until now has seldom been explored in depth and has rarely if ever been treated in a holistic manner.

Lifelong learning, the arts and community cultural engagement in the contemporary university: International perspectives Edited by Darlene Clover and Kathy Sanford

Knowledge, democracy and action: Community-university research partnerships in global perspectives Edited by Budd Hall, Edward Jackson, Rajesh Tandon, Jean-Marc Fontan and Nirmala Lall

University engagement and environmental sustainability Edited by Patricia Inman and Diana L. Robinson

A new imperative: Regions and higher education in difficult times Michael Osborne, Chris Duke and Bruce Wilson 


\title{
Higher education in a globalising world
}

Community engagement and lifelong learning

\author{
Peter Mayo
}

Manchester University Press 
Copyright (C) Peter Mayo 2019

The right of Peter Mayo to be identified as the author of this work has been asserted by him in accordance with the Copyright, Designs and Patents Act 1988.

Published by Manchester University Press

Altrincham Street, Manchester M1 7JA

www.manchesteruniversitypress.co.uk

British Library Cataloguing-in-Publication Data

A catalogue record for this book is available from the British Library

ISBN 9781526140920 hardback

First published 2019

The publisher has no responsibility for the persistence or accuracy of URLs for any external or third-party internet websites referred to in this book, and does not guarantee that any content on such websites is, or will remain, accurate or appropriate.

Typeset by Newgen Publishing UK 